\title{
EFEKTIFITAS BUAH BIT (BETA VULGARIS) SEBAGAI DISCLOSING SOLUTION (BAHAN IDENTIFIKASI PLAK)
}

\author{
Diyah Fatmasari ${ }^{\star}$ Setiadji Musthofa ${ }^{\star}$,Bedjo Santoso ${ }^{\star}$
}

\begin{tabular}{|c|c|}
\hline & ABSTRACT \\
\hline $\begin{array}{l}\text { Keywords: } \\
\text { bit fruit, disclosing } \\
\text { solution, plaque } \\
\text { identification }\end{array}$ & $\begin{array}{l}\text { Background: Bit fruit (Beta vulgaris) is plants as group of vegetables, } \\
\text { has potencial as a source of natural dyes for food products. In dental } \\
\text { health, a coloring agent which has contrast color with teeth is used for } \\
\text { dental plaque identification. Disclosing solution is the most common }\end{array}$ \\
\hline & $\begin{array}{l}\text { bit fruit can substitute disclosing solution as coloring agent for plaque } \\
\text { identification. Method: Research design was Quasi Eksperimental } \\
\text { Research.with Posttest Only Control Group Design. Samples was } \\
36 \text { elementary students which divided into } 2 \text { groups. Group } 1 \text { was } 18 \\
\text { students given disclosing solution while group } 2 \text { was given bit fruit } \\
\text { solution. Independent t test was used to determine diferences between } \\
\text { two groups. Result: Research results showed mean of plaque index } \\
\text { after application of bit fruit and disclosing solution was } 3,75 \text { and } 2,66 \text {, } \\
\text { with independent t-test resulten significancy } 0,000<0,05 \text {. There was } \\
\text { differences of plaque index after two group of application. Conclusion: } \\
\text { the bit fruit was more effective to determine plaque compared to } \\
\text { disclosing solution. }\end{array}$ \\
\hline
\end{tabular}

\section{PENDAHULUAN}

Plak adalah suatu lapisan yang melekat pada gigi, terdiri dari kuman-kuman dari ludah dan sisa makanan. Plak tidak bisa dilihat karena warnanya transparan seperti warna kaca putih tembus cahaya. Cara melihat plak digunakan zat pewarna (merah/ungu) yang berupa cairan disebut disclosing solution". Tetapi dalam aplikasinya, disclosing solution mempunyai kekurangan yaitu mengandung bahan kimia diantaranya Kalium Jodida, Kristal Jodium, Air, dan Glisein.

Sejak zaman dahulu telah banyak buah dan sayuran yang berpotensi sebagai sumber bahan pewarna alami, salah satunya yaitu buah bit. Bit (Beta vulgaris) merupakan tanaman semusim yang berbentuk rumput ${ }^{2}$. Bit banyak digemari karena rasanya enak, sedikit manis, dan lunak mengandung betasianin yang merupakan pigmen bewarna merah- violet. Hingga saat ini pigmen betasianin yang telah diproduksi dalam skala besar hanya berasal dari buah bit. Salah satu syarat disclosing sebagai zat pewarna plak adalah warnanya harus kontras dengan warna gigi dalam mulut ${ }^{1}$. Tujuan penelitian ini adalah untuk melihat efektifitas buah bit sebagai alternatif pengganti disclosing solution.

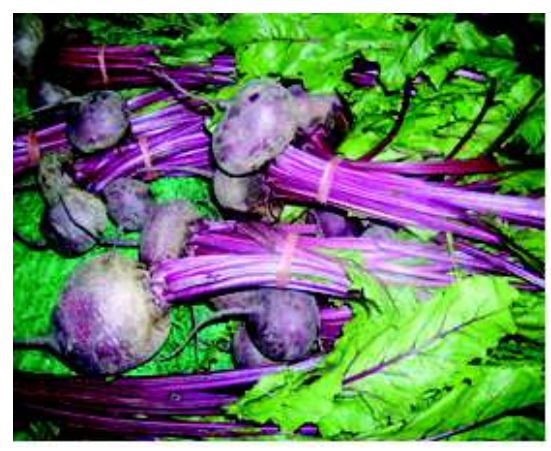

Gambar 1. Buah Bit

*Staf Pengajar Jurusan Keperawatan Gigi Politeknik Kesehatan Kemenkes Semarang Korespondesi: fatmasaridiyah@gmail.com 


\section{METODE PENELITIAN}

Desain penelitian yang digunakan dalam penelitian ini adalah (Post test Only Control Group Design). Dengan rancangan ini, memungkinkan peneliti mengukur pengaruh perlakuan pada kelompok eksperimen dengan cara membandingkan kelompok tersebut dengan kelompok kontrol. Sampel penelitian adalah siswa kelas V SD Negeri Tinjomoyo 01 yang berjumlah 36 orang.

Variabel pengaruh adalah sari buah bit dan disclosing solution, variabel terpengaruh plak gigi (PHP-M), variabel terkendali yaitu cara pengambilan sari buah bit, dan volume buah bit serta variabel tak terkendali adalah susunan gigi dan saliva

Prosedur penelitian adalah:

1. Mempersiapkan sari buah bit dan disclosing solution.

2. Membagi sampel menjadi kelompok kontrol dan kelompok eksperimen.

3. Memberikan pengarahan pada masing-masing kelompok untuk mempraktekkan cara pengolesan cairan sari buah bit dan disclosing solution.

4. Memberikan instruksi kepada semua responden untuk memakan biskuit untuk menyamakan sampel sebelum dilakukan perlakuan.

5. Melakukan perlakuan pada masing-

IP PHP $=\frac{\text { Jumlah skor plak seluruh permukaan gigi yang diperik }}{\text { Jumlah gigi yang diperiksa }}$

masing kelompok dengan pengolesan disclosing solution dan sari buah bit.

6. Memeriksa indeks plak gigi setelah seluruh permukaan gigi diolesi sari buah bit dan disclosing solution. Cara mengukur indek plak

7. Mencatat hasil pemeriksaan pada lembar pemeriksaan.

8. Analisis data
HASIL PENELITIAN

Tabel 1 Distribusi frekuensi kriteria Plak Indeks sesudah pengolesan disclosing solution

\begin{tabular}{crcc}
\hline \multirow{2}{*}{ No } & \multirow{2}{*}{ Kriteria } & \multicolumn{2}{c}{$\begin{array}{c}\text { Pengolesan } \\
\text { disclosing solution }\end{array}$} \\
\cline { 3 - 4 } & & $\mathbf{N}$ & $\%$ \\
\hline 1 & Baik $(0-1.7)$ & 1 & $5 \%$ \\
2 & Sedang $(1.8-3.4)$ & 14 & $78 \%$ \\
3 & Buruk $(3.5-5)$ & 3 & $17 \%$ \\
\hline & Jumlah & 18 & $100 \%$ \\
\hline & Rata-rata & \multicolumn{2}{c}{2,661} \\
\hline
\end{tabular}

Dari tabel diatas dapat dilihat bahwa plak indeks sesudah pengolesan disclosing solution pada kelompok 1 yang paling tinggi persentasenya yaitu pada kriteria sedang dengan jumlah 14 responden (78\%).

Tabel 2 Distribusi frekuensi kriteria Plak Indeks sesudah pengolesan sari buah bit

\begin{tabular}{llcc}
\hline \multirow{2}{*}{ No } & \multicolumn{1}{c}{ Kriteria } & \multicolumn{2}{c}{$\begin{array}{c}\text { Pengolesan sari } \\
\text { buah bit }\end{array}$} \\
\cline { 3 - 4 } & & $\mathbf{n}$ & $\mathbf{\%}$ \\
\hline 1 & Baik $(0-1.7)$ & 0 & $0 \%$ \\
2 & Sedang $(1.8-3.4)$ & 3 & $17 \%$ \\
3 & Buruk $(3.5-5)$ & 15 & $83 \%$ \\
\hline \multirow{2}{*}{ Jumlah } & 18 & $100 \%$ \\
\hline & Rata-rata & \multicolumn{2}{c}{3,755} \\
\hline
\end{tabular}

Dari tabel 2 dapat dilihat bahwa plak indeks sesudah pengolesan sari buah bit pada kelompok 2 yang paling tinggi persentasenya yaitu pada kriteria buruk dengan jumlah 15 responden (83\%).

Tabel 3. Nilai rata-rata indeks plak sesudah pengolesan buah bit dan disclosing solution

\begin{tabular}{cccc}
\hline \multirow{2}{*}{ Disclosing solution } & \multicolumn{2}{c}{ Buah Bit } \\
\hline $\mathrm{n}$ & Mean & $\mathrm{n}$ & Mean \\
\hline 18 & 2,661 & 18 & 3,755 \\
\hline
\end{tabular}




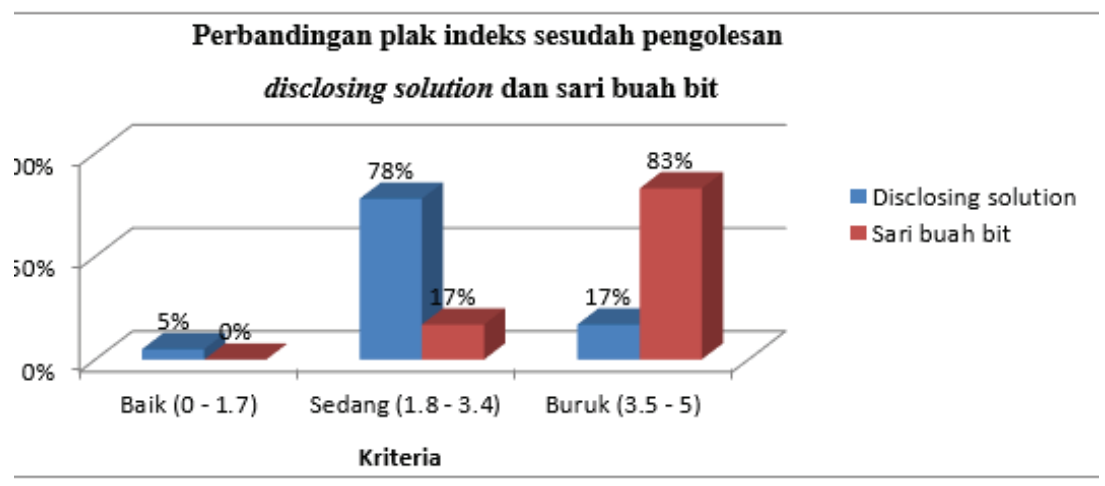

Gambar 2. Perbandingan plak indeks sesudah pengolesan disclosing solution dan pengolesan sari buah bit

Berdasarkan gambar dapat dilihat bahwa terjadi perbedaan nilai ratarata indeks plak antara perlakuan dengan buah bit dan disclosing solution. Perbedaan rata-rata indeks plak tersebut apakah benar-benar nyata berbeda atau tidak, maka data yang diperoleh dianalisis dengan uji statistik T-Test. Berdasarkan uji normalitas dan homogenitas didapatkan hasil sebagai berikut :

Tabel 4. Hasil uji normalitas dan homogenitas data

\begin{tabular}{ll}
\hline & Kemaknaan \\
\hline Kolmogrov-Smirnov & $0,646^{*}$ \\
Homogeneity of Variances & $0,122^{*}$ \\
\hline
\end{tabular}

Berdasarkan tabel 4 diketahui nilai Kolmogrov-Smirnov dan nilai Homogenity of Variances $>0,05$, maka data adalah normal dan homogen. Selanjutnya dapat dilakukan uji parametrik uji independent T-Test.

Tabel 5. Hasil uji beda dengan independent T-Test

\begin{tabular}{cccc}
\hline Nilai F & Nilait & $\begin{array}{c}\text { Derajat } \\
\text { Kebebasan }\end{array}$ & $\begin{array}{c}\text { Nilai } \\
\text { Kemaknaan }\end{array}$ \\
\hline 2,512 & 6,372 & 34 & 0,000 \\
\hline
\end{tabular}

Berdasarkan tabel 5 dapat dilihat nilai signifikasi $<0,05$, maka ada perbedaan nilai indeks plak, artinya terdapat perbedaan nilai indeks plak pada gigi setelah peneliti melakukan eksperimen dengan sari buah bit dan disclosing solution. dapat disimpulkan bahwa untuk melihat plak pada gigi, buah bit lebih efektif dibandingkan dengan disclosing solution.

\section{DISKUSI}

Pada kelompok sampel sebelum perlakuan diintruksikan untuk memakan biskuit yang diberikan oleh peneliti. Hal ini bertujuan agar dapat menghasilkan plak baru dan menghomogenkan perlakuan pada kelompok sampel. Plak yang baru terbentuk bersifat lunak akan mudah dibersihkan dengan bersikat gigi ${ }^{3}$. Bila dibiarkan makin lama makin tebal. Tetapi dalam waktu sekitar satu jam akan terbentuk pelikel, selaput lendir dari ludah yang menyelimuti gigi. Lapisan ini tipis, tembus cahaya dan tidak mengandung bakteri serta tidak mempunyai struktur tertentu dan disebut aquired pellicle. Setelah aquired peliicle terbentuk, bakteri mulai berproliferasi diatas permukaan pelikel. Pelikel yang telah diduduki oleh bakteri akan menjadi bagian dari plak.

Setelah sampel diberi instruksi untuk memakan biskuit, peneliti melakukan perlakuan pengolesan disclosing solution dan sari buah bit pada masing-masing kelompok. Kemudian peneliti menghitung plak indeks pada masing-masing responden. Setelah gigi diolesi sari 
buah bit, didapatkan hasil nilai rata-rata indeks plak sebesar 3,755. Demikian pula pada kelompok sampel setelah diolesi disclosing solution didapatkan nilai ratarata sebesar 2,661. Sehingga terdapat selisih indeks plak antara buah bit dan disclosing solution adalah 1,094.

Bahan yang digunakan untuk melihat plak adalah dengan menggunakan zat warna. Zat warna ini, dapat berupa cairan maupun tablet ${ }^{4}$. Setelah dilakukan eksperimen dengan buah bit dan disclosing solution, didapatkan selisih sebesar 1,904. Selisih tersebut disebabkan kandungan disclosing solution dengan bahan dasar iodine sebesar 1,6 gram, kalium iodide 1,6 gram, air 13,4 ml dan gliserin sampat didapatkan larutan sebanyak $30 \mathrm{ml}$. Sedangkan kandungan buah bit yaitu betasianin yang akan berubah menjadi merah keunguan apabila dicampur dengan asam. Warna merah bit segar ini disebabkan oleh kandungan pigmen betasianin sekitar $70-90 \%$ dimana konsentrasi yang tinggi ini sering digunakan sebagai pewarna atau sebagai bahan tambahan pangan karena dapat meningkatkan kesehatan. Betasianin merupakan zat yang larut di dalam air yang memiliki efek antimikroba dan antivirus. Betasianin juga stabil dan cocok pada subjek dengan $\mathrm{pH}$ rendah atau asam $^{5}$. sehingga warna sari buah bit dapat lebih mudah menempel pada plak daripada menggunakan disclosing solution. Dari hasil penelitian ini dapat diketahui bahwa buah bit lebih efektif digunakan untuk menggantikan disclosing solution untuk melihat plak.

\section{KESIMPULAN}

1. Nilai rata-rata indeks plak gigi setelah dilakukan dengan sari buah bit adalah sebesar 3,755. Sedangkan nilai ratarata indeks plak setelah dilakukan perlakuan dengan disclosing solution adalah sebesar 2,661.

2. Selisih rata-rata plak indeks sesudah perlakuan pengolesan sari buah bit dan disclosing solution sebesar 1,094.

3. Hasil uji statistik independent t-test dihasilkan angka signifikasi $\quad 0,000$ $<0,05$, maka ada perbedaan setelah dilakukan pengolesan sari buah bit dan disclosing solution terhadap angka plak indeks.

\section{DAFTAR PUSTAKA}

1. Putri, dkk, 2011, I/mu Pencegahan Penyakit Jaringan Keras dan Jaringan Pendukung Gigi, EGC, Jakarta

2. Yanti, Febri, 2012, Pengaruh Suhu Terhadap Mutu Bubuk Pewarna MakananAlami DariBuah Bit (Beta Vulgaris L), http://digilib.unimed.ac.id/ UNIMED-Undergraduate-0122021/22544/ buah-bit, diakses pada tanggal 8 Juni 2014 jam 13.00 WIB.

3. Ircham M, 1993, Penyakit-Penyakit Gigi dan Mulut Pencegahan dan Perawatannya, Liberty, Yogyakarta

4. Yuwono, Lilian, 2000, Pencegahan Penyakit Mulut (Preventive Dentistry), Hipokrates, Jakarta.

5. Rizki, Farah, 2013, The Miracle of Vegetables, AgroMedia, Jakarta. 